\title{
SELF-MEDICATION PRACTICES AND PERCEPTIONS AMONG UNDERGRADUATE MEDICAL STUDENTS OF MULTAN MEDICAL \& DENTAL COLLEGE, MULTAN
}

\author{
Asif Noor ${ }^{1}$, Ejaz Hussain Sahu ${ }^{2}$, Muhammad Umer Abdullah ${ }^{3}$ and Aftab Yousaf ${ }^{4}$ \\ ${ }^{1,2}$ Assistant professor, Department of Community Dentistry, Multan Medical \& Dental College, Multan. \\ ${ }^{3}$ Assistant Professor, Department of Oral Pathology, Multan Medical \& Dental College, Multan. \\ ${ }^{4}$ Demonstrator, Department of Community Dentistry, Multan Medical \& Dental College, Multan \\ Correspondence: Dr. Aftab Yousaf. aftabyousafemsph13@hsa.edu.pk.
}

\begin{abstract}
Background: Self-medication can be defined as "the drugs which are used to treat self-diagnosed disorders or indications, or the irregular or continued use of a prescribed drug for persistent or recurrent disease or symptoms."

Methods: A descriptive cross sectional study was performed to understand the perceptions and practices about self-medication among students admitted to one of medical colleges in Pakistan located in Multan. A structured Questionnaire was distributed to the consenting students. The data were coded, entered and analyzed by using the Statistical Package for Social Science (SPSS) version 20.0. Out of 95 medical students $47.7 \%(n=45)$ were males and $52.3 \%(n=55)$ were females.

Results: Among participants, self-medication was found in $98 \%(n=93)$ cases. Among self-medication respondents, more than $50 \%$ treated themselves only once while $32 \%$ twice, $12 \%$ thrice and only $2.1 \%$ more than thrice. Self-medication was equally common in 3rd year, fourth year and final year medical students. While $24.2 \%$ of respondents perceived as a good practice, $42.1 \%$ took it as an acceptable practice while $33.7 \%$ were of opinion that it was a totally unacceptable practice. The study revealed different reasons for self medication and found that the most common reason was non-seriousness of disease i.e $43.2 \%$, followed by convenience / time factor $42.1 \%$, Cost saving $13.7 \%$ and least one was the non-availability of physician $1.1 \%$. Regarding the use of drugs, antibiotics were the most common class used as self-medication $27.4 \%$, followed by anti allergics $23.2 \%$, vitamins $17.9 \%$, pain killers $16.8 \%$ and antacids in $14.7 \%$ cases.
\end{abstract}

Conclusion: The study results indicate that Self medication was common among medical students from clinical classes and most of students treated themselves at least once.

Key words: Self-medication, practices, perceptions, college students.

\section{Introduction:}

Self-medication can be defined as the drugs which are used to treat self-diagnosed disorders or indications, [1] it involves using medicines without a prescription, use of old prescriptions to buy medicines[2].Self-medication can lead to inappropriate use of drugs, waste of income, increased resistance of pathogens which can lead to serious health problems, possible undesirable and serious drug reactions and prolonged morbidity [3]. In developing countries like Pakistan, where drugs are available without prescription and health service provision is insufficient to meet the needs of the population self-medication is rampant [4].Self medication can be attributed to various factors i.e., socioeconomic and socio-demographic factors, easy accessibility of drugs, pharmaceutical advertisement, previous medical history and left over medicines at home. Moreover an emerging source is internet in most educated individuals.[5] The World Health
Organization has emphasized that self medication must be correctly taught and controlled.[1] In a survey of West Bengal, India undergraduate medical school students, $57 \%$ reported self-medicating. The type of drugs most frequently used for self-medication were antibiotics (31\%), analgesics $(23 \%)$, antipyretics $(18 \%)$, antiulcerics $(9 \%)$, cough suppressants $(8 \%)$, multivitamins (6\%), and anthelmintics (4\%).[4] Another study indicated that $53 \%$ of physicians in Karnataka, India reported self-administration of antibiotics.[6] Another study at An-Najah National University showed that $98 \%$ of medical and nonmedical students practiced self-medication [7].In Bahrain, a study which was conducted among first year medical students, $76.9 \%$ of the study population preferred self-medication [8]. The habit of selfmedication practice among doctors develops during their undergraduate training as obvious from studies of self-medication among medical students.[9] For medical undergraduates such practice has special 
significance as they are exposed to knowledge about diseases and drugs and availability of drugs on pharmacies due to their medical background, especially in Pakistan. This study was performed to understand the practices and perception of selfmedication among undergraduate medical students in one of medical colleges in Pakistan, located in Multan.

Methodology: A descriptive cross sectional study was undertaken to be familiar with perceptions and practices of medical students of Multan Medical \& Dental College about self-medication. Simple Random Sampling technique was used to identify the potential sample. Sample size was calculated using the below mentioned formula and prevalence of selfmedication in Pakistan according to a study done at Karachi.[10][11] i.e. 51\%, the calculated sample size is 95. All undergraduate students from clinical side third, fourth and final year were included in study. Students currently on any drug regime for acute or chronic physical or mental illness were excluded from the study. A structured Questionnaire was distributed to the consenting students. The self-administered questionnaire consisted of 26 questions, which collected data regarding demographic, socioeconomic, and lifestyle factors. Students were asked to indicate if they had used any drugs in last 15 days, the duration and pattern of use, which drugs they had used, and whether the drugs had been prescribed by a doctor. The data were coded, entered and analyzed by using the Statistical Package for Social Science (SPSS) version 20.0.

\section{Results:}

Comparison of different diseases and use of selfmedication for different diseases are presented in figure-1. A total of 95 medical students were given questionnaire. The response rate was $100 \%$. The mean age of the respondents was $22.22 \pm 1.7 \mathrm{~S}$. Out of 95 medical students $47.7 \% \quad(n=45)$ were males and $52.3 \%(n=55)$. Among participants, self-medication was found in $98 \%$ ( $n=93)$ cases. More than $50 \%$ of the positive respondents treated themselves only once, while $32 \%$ self medicated themselves twice during the last six months, while only $2.1 \%$ of the positive subjects went for self medication more than three times during last six month. Self-medication was equally common in 3rd year, fourth year and final year medical students. All $(n=95)$ respondents knew about self-medication. $24.2 \%$ of the respondent perceived self-medication as a good practice while for $42.1 \%$ it was an acceptable practice and $33.7 \%$ took it as totally unacceptable practice. The study revealed different reasons for self medication and found that $43.2 \%$ of the people practiced it assuming the nonseriousness of the disease. While $42.1 \%$ practiced it for their convenience and time saving, $13.7 \%$ choose it to save cost, while only $1.1 \%$ had issue of nonavailability of physicians as the study population was already spending more than six hours in a teaching hospital (table-1).

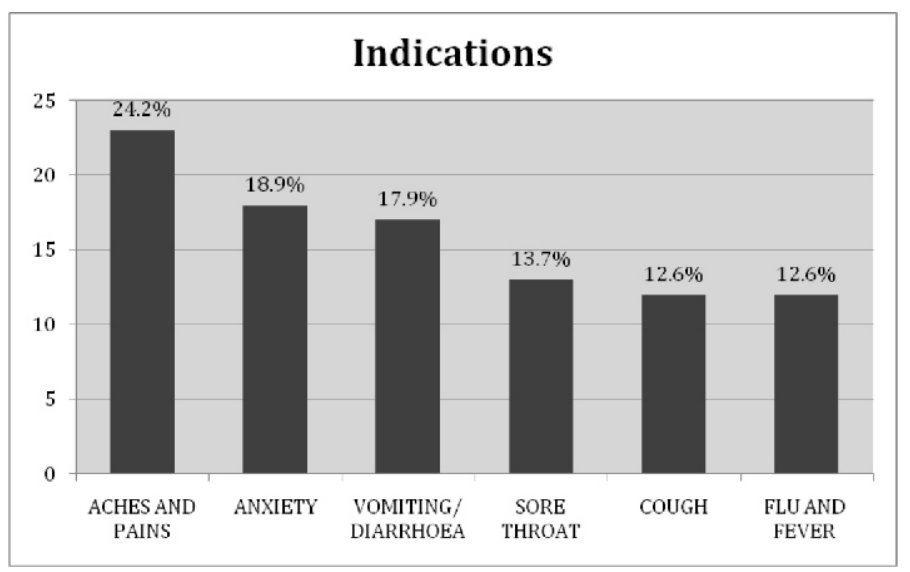

Figure 1: Bar graph shows comparison of SelfMedication practice for different diseases

Table 1: Frequency distribution according to Source of information regarding Self-medication

\begin{tabular}{|c|c|c|}
\hline $\begin{array}{c}\text { Source of } \\
\text { information }\end{array}$ & Frequency & Percentage (\%) \\
\hline $\begin{array}{c}\text { Previous Doctor } \\
\text { Prescription }\end{array}$ & 28 & 29.5 \\
\hline $\begin{array}{c}\text { Opinion of family } \\
\text { members / friends }\end{array}$ & 25 & 26.3 \\
\hline $\begin{array}{c}\text { The advertisement } \\
\text { /Media/Net }\end{array}$ & 22 & 23.2 \\
\hline $\begin{array}{c}\text { Recommendations } \\
\text { by Pharmacist }\end{array}$ & 20 & 21.1 \\
\hline
\end{tabular}

\section{Discussion:}

Self-care, including self-medication, has been a feature of healthcare for many years and people have always been keen to accept more personal responsibility for their health status [12]. Selfmedication by itself has both pros and cons that depend on who and what one chooses to self medicate [13]. Several studies have reported the practice of self-medication in medical and nonmedical students. The present study showed that selfmedication was widely practiced by the medical students of the institute. The prevalence of selfmedication in our study was found to be $97.8 \%$. While in other studies, the prevalence of self-medication among the medical students was shown to be ranging between $57.1 \%$ and $92 \%$ [14-16] . The students from non-medical background showed a prevalence of $80.1 \%$ in Tamil Nadu [17] and $87 \%$ in Uttar Pradesh [18]. In studies conducted in developing countries, the prevalence of self-medication was shown to be $25.4 \%$ and $43.2 \%$ in Ethiopia [19,20], 51\% in Slovenia [21] , $55 \%$ in Egypt [22], 56.9\% in Nigeria [23] and $80.9 \%$ in Malaysia [24]. Similarly, a nine-year follow-up study of 
a nationwide sample from Norway has reported a selfprescribing behavior among young doctors [25] .The results of our study show high prevalence then other developing countries. In our study, antibiotics were most commonly used as self-medication $(27.4 \%)$, followed by anti allergics $(23.2 \%)$, vitamins $(17.9 \%)$, pain killers (16.8\%) and antacids (14.7\%). The results of our study were correlated with the study by Sohair $\mathrm{E}$ Ali et al [26] which revealed that analgesics \& antipyretics $(30.2 \%)$, ear, nose \& throat drugs $(10.8 \%)$, vitamins \& minerals $(10.8 \%)$, GIT drugs $(8.5 \%)$, anti-infectives $(7.3 \%)$ and herbal medicines $(3.5 \%)$ were commonly self medicated and similar were the findings of Patel MM et al [27] which showed that $43.03 \%$ of pain-relievers. $21.51 \%$ cough remedies. $7.27 \%$ of Antimicrobials were self medicated commonly. In the present study, different reasons for self-medication were found. Most common being the disease not serious $(43.2 \%)$ followed by convenience / time factor (42.1\%), Cost saving $(13.7 \%)$ and least one was the non-availability of physician $(1.1 \%)$. The results compared with the study by AnsamF.sawalha et al [28] also reported that the most commonly reported reason for selfmedication practices was simplicity of the illness encountered. Analgesics, decongestants, herbal medicines and antibiotics were the most common classes reported in self-medication. According to the Economic Survey of Pakistan (2006-2007)[29], there was one doctor available for 1254 people whereas a WHO criterion for developing countries is minimum one doctor for 1000 population (Economic survey of Pakistan, 2006-2007). In Pakistan, almost every pharmacy sells drugs without a prescription; a phenomenon seen in many developing countries (Kiyingi and Lauwo, 1993)[30]. The relative low cost is important factor for resorting to self-medication and undesirable health seeking behavior.

\section{Conclusion}

The study results indicate that Self medication is common among medical students from clinical classes and most of students treated themselves at least once.

\section{References}

1. World Health Organization: Guidelines for the regulatory assessment of Medicinal Products for use in self-medication 2000 . http://apps.who.int/medicinedocs/pdf/s2218e/s2 218e.pdf

2. Loyola Filho Al, Lima-Costa MF, Uchôa E. Bambuí Project: a qualitative approach to self$\mathrm{m}$ e d i c a t i o n. C a d S a u d e Publica.2004;20(6):1661-69.

3. World Health Organization: Report of the WHO Expert Committee on National Drug Policies $1 \quad 9 \quad 9 \quad 5$ http://apps.who.int/medicinedocs/documents/51 6221e/s16221e.pdf.
4. Banerjee I, Bhadury T. Self-medication practice among undergraduate medical students in a tertiary care medical college, West Bengal. J Postgrad Med. 2012;58:127-31.

5. Klemenc-Ketis Z, Hladnik Z, Kersnik J. A cross sectional study of sex differences in selfmedication practices among university students in Slovenia. CollAntropol. 2011;35:329-34.

6. Deshpande SG, Tiwari R; Self medication--a growing concern. Indian J Med Sci, 1997;51: 936.

7. Sawalha AF. A descriptive study of selfmedication practices among Palestinian medical and nonmedical university students. Res. Social. Adm. Pharm.,2008; 4 (2):164-172

8. James $\mathrm{H}$, Handu SS, Al Khaja KA, Otoom S, Sequeira RP. Evaluation of the knowledge, attitude and practice of self-medication among first-year medical students. Med. Princ. Pract.,2006;15 (4): 270- 275

9. Medical, Pharmacy, Health Science Students in Gondar University, Ethiopia. Journal of Young Pharmacists, 2010; 2(3): 306-310.

10. Syed Nabeel Zafar, Reema Syed, Sana Waqar,Akbar Jaleel Zubairi, TalhaVaqar; Selfmedication amongst University Students of Karachi: Prevalence, Knowledge and Attitudes;Vol. 58, No. 4, April 2008 214-217J Pak MedAssoc

11. Haider S, Thaver IH, Self medication or self care: implication for primary health care strategies. J Pak Med Assoc 1995; 45: 297-8

12. Khantzian, E.J. The self-medication hypothesis revisited: The dually diagnosed patient. Primary Psychiatry.2003;10, 47-48, 53-54.

13. Hughes CM, McElnay JC, Fleming GF; Benefits and risks of self medication. Drug Saf, 2001; 24: 1027-1037.

14. Banerjee I, Bhadury T (2012) Self-medication practice among undergraduate medical students in a tertiary care medical college, West Bengal J Postgrad Med 2012;58(2):127-131.

15. Sontakke SD, Bajait CS, Pimpalkhute SA, Jaiswal KM, Jaiswal SR (2011) Comparative study of evaluation of self-medication practices in first and third year medical students. Int J Biol Med Res 2011;2(2): 561-564.

16. Badiger $S$, Kundapur $R$, Jain A, Kumar A, Pattanshetty S, et al. (2012) Selfmedication patterns among medical students in South India. Australas Med J 2012;5(4):217-220.

17. Kayalvizhi S, Senapathi R (2010) Evaluation of the perception, attitude and practice of selfmedication among business students in 3 select cities, South India. IJEIMS;1(3):40-44. Available: http://www.ijcns.com/pdf/40-44. 
Accessed:2013 Feb 27.

18. Verma RK, Mohan L, Pandey M (2010) Evaluation of self medication among professional students in North India: proper statutory drug control must be implemented. Asian J Pharmaceutical Clin Res 2010;3(1) 60-64.

19. Abay SM, Amelo W (2010) Assessment of selfmedication practices among medical, pharmacy, and health science students in Gondar University, Ethiopia. J Young Pharm 2010; 2(3):306-310.

20. Gutema GB, Gadisa DA, Kidanemariam ZA, Berhe DF, BerheAH, et al. Self-Medication Practices among Health Sciences Students: The Case of Mekelle University J Appl Pharmaceutical Sci 2011;01(10):183-189

21. Smogavec M, Softic ${ }^{2} N$, Kersnik J, KlemencKetis ${ }^{\sim}$ Z An overview of selftreatment and selfmedication practices among Slovenian citizens Slovenian Med J 2010;79:757-763.

22. El Ezz NF, Ez-Elarab HS .Knowledge, attitude and practice of medical students towards selfmedication at Ain Shams University, Egypt J Prev Med Hyg 2011; 52(4):196-200.

23. Fadare JO, Tamuno I .Antibiotic self-medication among university medical undergraduates in Northern Nigeria.J Public Health Epidemio $2011 ; 13(5)$ : 217-220.

24. Ali SE, Ibrahim MIM, Palaian S .Medication storage and self-medication behaviour amongst female students in Malaysia. Pharm Pract 2010;8(4):226-232.

25. Hem E, Stokke G, Tyssen R, Grønvold NT, Vaglum $P$, et al. Selfprescribing among young Norwegian doctors: a nine-year follow-up study of a nationwide sample. BMC Med 2005;3:16.

26. Sohair E Ali, Mohamed I Ibrahim, SubishPalaian;Medication storage and selfmedication behaviour amongst female students in Malaysia;pharmacy practice, Vol 8 , No 4 (2010)

27. Patel MM, Singh U, Sapre C, Salvi K, Shah A, Vasoya B. Self-Medication Practices among College Students: A Cross Sectional Study in Gujarat. Natl J Med Res. 2013; 3(3):257-260

28. AnsamF.sawalha; assessment of selfmedication practice among university students in palistine: therapeutic and toxicity implications. 2007; 15(2): 67-82

29. Economic survey of Pakistan. Ministry of Finance, Government of Pakistan (2006-2007)

30. Kiyingi KS, Lauwo JAK. Dangers in the home: danger and waste. World Health Forum 1993; 14: 381-384 